and macrophages in tissue culture. Int. Arch. Allergy, 43: 671 (1972).

8. Holm, G., Engwall, E., Hammarström, S., and Natvig, J. B.: Antibody-induced hemolytic activity of human blood monocytes. The role of antibody class and subclass. Scand. J. Immunol., 2: 173 (1974).

9. Holm, G., and Hammarström, S.: Haemolytic activity of human blood monocytes. Lysis of human erythrocytes treated with anti-A serum. Clin. Exp. Immunol., 13: 29 (1973).

10. Huber, H., Douglas, S. D., and Fudenberg, H. H.: The IgG receptor: An immunological marker for the characterization of mononuclear cells. Immunology, 17: 7 (1969).

11. Huber, H., and Fudenberg, H. H.: Receptor sites of human monocytes for IgG. Int. Arch. Allergy, 34: 18 (1968).

12. LoBuglio, A. F., Cotran, R. S., and Jandl, J. H.: Red cells coated with immunoglobulin $\mathrm{G}$ : Binding and sphering by mononuclear cells in man. Science, 158: 1582 (1967).

13. MacDonald, H. R., Bonnard, G. D., Sordat, B., and Zawodnik, S. A.: Antibody-dependent cell-mediated cytotoxicity: Heterogeneity of effector cells in human peripheral blood. Scand. J. Immunol., 4: 487 (1975).

14. Mancini, G., Carbonara, A. O., and Heremand, J. F.: Immunochemical quantitation of antigens by single radial immunodiffusion. Immunochemistry, 2: 235 (1965)

15. Trinchieri, G., Baumann, P., De Marchi, M., and Tökés, Z.: Antibody-dependen cell-mediated cytotoxicity in human: I. Characterization of the effector cell. J. Immunol., 115: 249 (1975).
16. Gibco, Grand Island, N. Y

17. Kindly provided by our local Red Cross Blood Transfusion Center.

18. Institut fur Reactorforschung, Würenlingen, Switzerland.

19. Division American Hospital Supply Corporation, Miami, Fla

20. Milian Instruments, Geneva, Switzerland.

21. Nuclear-Chicago, Chicago, Ill.

22. Informed consent was obtained from the children's mothers before all testing was done.

23. We are much indebted to Dr. B. de Wuilleret and to Mrs. C. Boumghar-Cachin (Red Cross Blood Transfusion Center, Lausanne) for providing excellent advice and assistance during this work. We are grateful to Dr. A. C. Campbell for his assistance in the preparation of this manuscript.

24. The present address of Dr. H. R, MacDonald is: Radiobiology Section, Ontario Cancer Foundation, Victoria Hospital, London, Ontario NGA 4G5 (Canada).

25. The present address of Dr. G. D. Bonnard is: Laboratory of Immunodiagnosis, National Cancer Institute, Bethesda, Md. 20014 (USA).

26. This work was supported by grants of the Swiss National Foundation for Scientific Research. Dr. H. R. MacDonald was supported by a postdoctoral fellowship from the Medical Research Council of Canada and Dr. G. D. Bonnard in part by the Foundation of the Swiss Academy of Medicine.

27. Requests for reprints should be addressed to: S. A Zawodnik, M.D. Immunogenetic Laboratory, Department of Pediatrics, Hôpital Cantonal Universitaire, 1011 Lausanne (Switzerland).

28. Accepted for publication Arpil 1, 1976
Adenosine triphosphate hemoglobin synthesis erythroblasts fetus hypoxia

liver

\title{
Effect of Hypoxia on Erythroblasts from Avian Fetal Liver: Adenosine Triphosphate Levels and Hemoglobin Synthesis
}

\author{
A. L. SCHWARTZ, R. SCHWARTZ, AND H. C. SCHWARTZ 149 \\ Department of Pharmacology, Case Western Reserve University School of Medicine, Cleveland, Ohio; Section on \\ Reproductive and Developmental Medicine, Brown University Program in Medicine and the Department of \\ Pediatrics, Rhode Island Hospital, Providence, Rhode Island; Section of Developmental Medicine, \\ Department of Pediatrics, Stanford University School of Medicine, Stanford, California, USA
}

\section{Extract}

A system for the isolation and functional evaluation of fetal liver erythroblasts is described. Isolated erythroblasts were prepared from 14-day embryonic avian livers and incubated at various oxygen tensions $(0,5,12$, and $95 \%)$. The concentration of ATP in erythroblasts remained constant for at least $4 \mathrm{hr}$ at $37^{\circ}$, but was rapidly reduced by incubation in nitrogen. Protein synthesis as measured by $\mathrm{L}-\left[{ }^{14} \mathrm{C}\right]$ leucine incorporation into cell protein occurred at a linear rate in $5 \%, 12 \%$, and $95 \%$ oxygen, whereas little protein synthesis occurred at $0 \%$ oxygen. The effect of hypoxia on the type of hemoglobin synthesized was studied in this system by isolating the hemoglobin $A$, hemoglobin $D$, and hemoglobin $H$ fractions and determining the incorporation of $\mathrm{L}-\left[{ }^{1} \mathrm{C}\right]$ leucine. The major fraction, hemoglobin $\mathrm{A}$, contained most of the radioactivity; smaller amounts were present in hemoglobin $D$ and hemoglobin $H$, respectively. The relative proportion of each hemoglobin synthesized was not altered by oxygen from $5 \%$ to
95\%. These results argue against a direct effect of oxygen on the type of hemoglobin synthesized at this stage of development.

\section{Speculation}

Early in fetal development nonerythropoietin mechanisms for the regulation of erythropoiesis may exist. The hypoxic stimulus to erythropoiesis is mediated through erythropoietin in definitive erythroblasts, but may have a direct effect in primitive erythroblasts.

A major step towards therapy for sickle cell anemia and the thalassemia syndromes, the most common of the hereditary hemolytic anemias, would be an understanding of erythropoiesis during development. In man the pattern is probably like that in the avian embryo, where erythropoiesis develops from a primitive to a definitive cell with associated changes from embryonic to adult hemoglobins $(11,12,14,22,36,43)$. A similar developmen- 
tal pattern occurs in mouse as well as during morphogenesis of the bull frog $(2,31)$.

In the primitive cell line of the early avian embryo, the total hemoglobin contains approximately $70 \%$ hemoglobin P, $20 \%$ hemoglobin $\mathrm{E}$, and $10 \%$ hemoglobin $\mathrm{M}$. In the definitive cell line of the late embryo and adult, $75 \%$ of the total hemoglobin is hemoglobin A and $25 \%$ hemoglobin D $(9,10,36)$. A small percentage of "hatching" hemoglobin, hemoglobin $\mathrm{H}$, appears in late embryos and newly hatched chicks but not in the adult chicken $(9,10)$.

The differentiation of the definitive cell is for the most part responsive to erythropoietin, whereas primitive cells probably do not respond to erythropoietin $(35,37)$. Since avian fetal livers may contain both primitive and definitive erythroblasts, the present studies were undertaken to establish an in vitro model for the maintenance of fetal erythroblasts and to examine the effects of hypoxia on hemoglobin synthesis in such cells.

\section{MATERIALS AND METHODS}

All chemicals were of reagent grade. Enzymes were purchased from Sigma Chemical Co. L- $\left[{ }^{14} \mathrm{C}\right]$ Leucine (specific radioactivity $=10 \mathrm{mCi} / \mathrm{mmol}$ ) was purchased from New England $\mathrm{Nu}-$ clear Corp. Trypan blue in Hanks' balanced salt solutions was from Gibco. The stock solutions for the preparation of the cell isolation and incubation solutions were from Gibco: solution I was Hanks' balanced salt solution without $\mathrm{Ca}^{++}$, and with $2 \times$ glucose and bicarbonate, pH 7.40, and containing $1 \mathrm{mM}$ EGTA. This solution was gased with $95 \% \mathrm{O}_{2}: 5 \% \mathrm{CO}_{2}$ before use. Solution $I I$ was Eagle's minimal essential medium in Hanks' balanced salt solution without phenolphthalein with $2 \times$ glucose, $2 \times$ bicarbonate, $1 \times$ glutamine, $\mathrm{pH} 7.40$, and containing $52.4 \mathrm{mg} \mathrm{L}$ leucine/liter. This solution was gased with $95 \% \mathrm{O}_{2}: 5 \% \mathrm{CO}_{2}$ before use.

\section{CELL ISOLATION}

Isolated erythroblasts and hepatocytes were obtained from embryonic chick liver by a modification of the technique described by Hommes et al. (21) for the isolation of hepatocytes from fetal rat liver. Fourteen-day chick embryo livers were removed at room temperature and placed into ice-cold solution I. Each experiment required 36-48 eggs. All of the following procedures were performed at $4^{\circ}$ unless otherwise noted. The tissues were gently shaken in a mixture of approximately 1:10 (tissue to medium) for 15 min after which the tissue and medium were centrifuged for 15 $\min$ at $240 \times g$. The supernatant solution was decanted and fresh solution $I$ was added to resuspend the pellet. These steps of centrifugation and washing were repeated twice. At this stage virtually all hepatic tissue was dispersed into isolated cells or remained as a connective tissue structure. The pellet was then resuspended in solution $I I$ (containing $\mathrm{Ca}^{++}$and without EGTA) and filtered through four layers of cheesecloth to remove the connective tissue structure. The isolated cells were then washed four times with fresh solution II and centrifuged at $60 \times g$ for 5 min. Since hepatocytes are much larger and heavier than the erythroblasts, the two cell populations were separated by repeated centrifugation at $3.3 \times g$ for 5 min with washing. The settled cells were light brown. The supernatant solution was bright red and after centrifugation at $240 \times g$ for 5 min yielded a pellet of isolated erythroblasts and a clear supernatant solution. All incubation studies were performed in solution $I I$ and the cell concentration was approximately $1-1.5 \times 10^{8}$ cells $/ \mathrm{ml}$. The erythroblasts were evaluated as follows. (I) Light microscopy was performed on smears stained with Wright's stain. (2) Trypan blue exclusion was performed in the presence of $1 \%$ albumin. (3) ATP concentrations were determined in cells incubated at $4^{\circ}$ and $37^{\circ}$ in both oxygen and nitrogen environments. After incubation, $400 \mu \mathrm{l}$ cell suspension were homogenized in $50 \mu 1$ ice-cold $3 \mathrm{M}$ perchloric acid which contained $5 \mathrm{mM}$ EDTA. The supernatant solution was then mixed with $100 \mu 1$ ice-cold $2 \mathrm{M} \mathrm{KHCO}_{3}$. The resulting neutralized supernatant solution was assayed for ATP fluorimetrically with hexokinase and glucose-6-phosphate dehydrogenase according to the method of Lowry and Passoneau (29). Protein was assayed according to the method of Lowry et al. (30) with bovine serum albumin as a standard. The mean protein content per cell was approximately $90 \mathrm{pg}$. (4) As the experimental design required several hours of incubation in a variety of oxygen concentrations plus $5 \% \mathrm{CO}_{2}$, maintenance of constant $\mathrm{pH}$ was required. In preliminary experiments, the isolated erythroblasts were incubated at $37^{\circ}$ for up to $4 \mathrm{hr}$ in a sealed chamber containing $\mathrm{pH}$ electrodes, an oxygen electrode which was calibrated and coupled to a Keithly potentiometer (8), a gas inlet, a gas outlet, and a cell suspensionsampling outlet. During the 4-hr incubation, the $\mathrm{pH}$ was maintained between 7.38 and 7.40 .

\section{DETERMINATION OF HEMOGLOBIN SYNTHESIS}

Aliquots of a suspension of isolated erythroblasts were incubated at $37^{\circ}$ in one of the following gas mixtures: $\left(95 \% \mathrm{O}_{2}: 5 \%\right.$ $\left.\mathrm{CO}_{2}\right),\left(12 \% \mathrm{O}_{2}: 5 \% \mathrm{CO}_{2}: 83 \% \mathrm{~N}_{2}\right),\left(5 \% \mathrm{O}_{2}: 5 \% \mathrm{CO}_{2}: 90 \% \mathrm{~N}_{2}\right)$, or $\left(0 \% \mathrm{O}_{2}: 5 \% \mathrm{CO}_{2}: 95 \% \mathrm{~N}_{2}\right)$, L- $\left[{ }^{14} \mathrm{C}\right]$ Leucine $(5 \mu \mathrm{Ci})$ in $0.9 \% \mathrm{NaCl}$ was added to each tube containing $4 \mathrm{ml}$ of cell suspension. The tubes were sealed, gased for $5 \mathrm{~min}$ at $4^{\circ}$ and then placed in a metabolic shaking bath at $37^{\circ}$ with continuous gassing. To avoid altering the gas phase, samples were taken by removing aliquots of the cell suspension via a Gilson Minipuls pump. Aliquots taken for measurement of the rate of protein and hemoglobin synthesis were prepared as follows. The cells were packed by centrifugation and washed three times with $0.9 \% \mathrm{NaCl}$. The final pellet was lysed by addition of $150 \mu 1$ distilled water and stored frozen at $-15^{\circ}$. Subsequently the frozen lysates were thawed and $100 \mathrm{mg}$ carrier chicken hemoglobin were added. After sonication they were centrifuged in a microfuge at $10,000 \times g$ for $5 \mathrm{~min}$. The hemoglobin was present in the supernatant solution. The radioactivity of the trichloroacetic acid (TCA)-precipitable protein was determined in aliquots which contained $4 \mathrm{mg}$ hemoglobin.

Hemoglobin H, A, and D fractions were prepared from an aliquor of supernatant solution which contained $25 \mathrm{mg}$ hemoglobin by electrophoresis on a starch block in Veronal buffer, $\mathrm{pH} 8.6$, for $16 \mathrm{hr}(28)$. The hemoglobin fractions separated distinctly and the block was cut into seven bands as shown in Figure 1. Bands 2, 4, and 6 corresponded to hemoglobins $\mathrm{D}, \mathrm{A}$, and $\mathrm{H}$, respectively, and bands $1,3,5$, and 7 were the areas between the outside of these visible hemoglobin fractions. Each band was eluted with water and suctioned through a sintered glass filter. The hemoglobin concentration was measured and the total hemoglobin was either brought to $4 \mathrm{mg}$ with carrier hemoglobin or an aliquot containing $4 \mathrm{mg}$ was used. In all experiments, the carrier hemoglobin was obtained by hemolyzing the erythrocytes of 13-, 15-, and/or 17-day-old avian embryos. As shown in Figure 1, the proportion of the various hemoglobin fractions is very similar at those ages when examined by starch gel electrophoresis.

The radioactivity of the fractions was determined as follows. The proteins were precipitated with cold $10 \%$ TCA, were washed twice with $5 \%$ TCA which contained $50 \mathrm{mM}$ L-leucine, and were dissolved in $1.0 \mathrm{~N} \mathrm{NaOH}$. They were reprecipitated with $10 \% \mathrm{TCA}$ and washed once with $5 \%$ TCA containing $50 \mathrm{mM} \mathrm{L-leucine} \mathrm{and}$ once with 5\% TCA. The precipitates were suspended in water and after adding acetone were reprecipitated by the addition of $2 \mathrm{~N}$ $\mathrm{HCl}$. Acetone was again added and the decolorized, whitish precipitate was washed once with cold acetone. The precipitates were then washed twice with ethanol-ether $(3: 1, v / v)$, once at room temperature and once at $56^{\circ}$, washed twice with ether, and finally dissolved in $0.1 \mathrm{~N} \mathrm{NaOH}$. The protein concentration in an aliquot was determined (30) and another aliquot, which was dissolved in Aquasol: $\mathrm{H}_{2} \mathrm{O}(6: 1, v / v)$, was counted in a Tri-Carb liquid scintillation spectrometer. An internal standard was added to correct quenching in each sample. The counting efficiency was $45 \%$. The activity was expressed as specific activity (counts per min per mg protein) and/or total activity (total counts per min). 


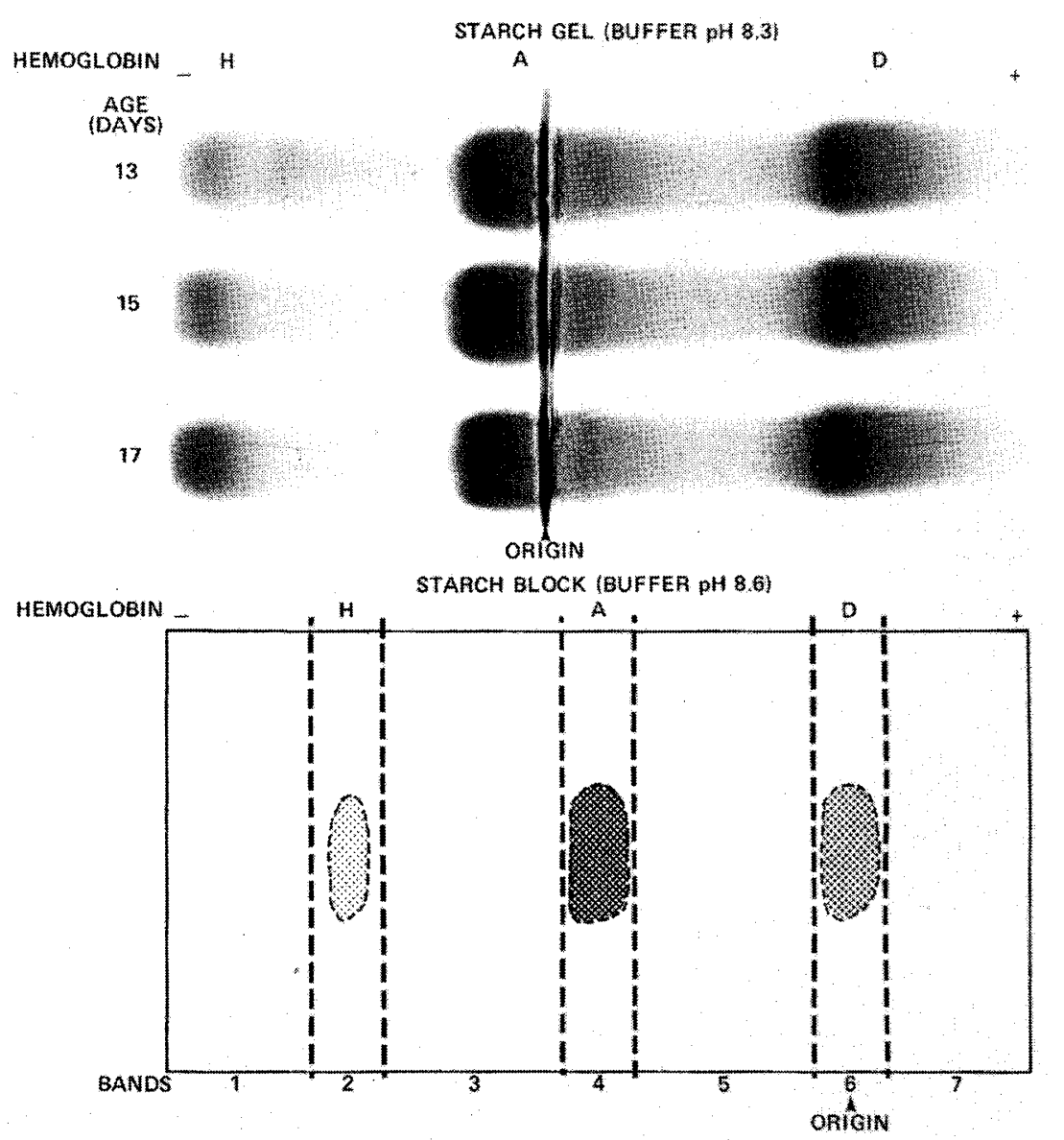

Fig. 1. Upper: electrophoretic pattern of hemoglobins H, A, and D separated on starch gel as described in the text. Lower: electrophoretic pattern of hemoglobins H, A, and D separated on starch block as described in the text. The block was cut along the broken line(- - ) and seven protein fractions were obtained.

\section{RESULTS}

\section{EVALUATION OF ISOLATED ERYTHROBLASTS}

Light microscopy revealed intact isolated cells with over $95 \%$ erythroblasts and less than $5 \%$ hepatocytes (Fig. 2). Over $95 \%$ of the cells effectively excluded trypan blue dye.

The biochemical viability of the cells was assessed by following cellular ATP concentrations. ATP concentrations from various preparations were approximately $5 \mathrm{nmol} / \mathrm{mg}$ protein. As seen in Figure $3 A$, cellular ATP levels were maintained at constant levels for at least $4 \mathrm{hr}$ at $37^{\circ}$ in an oxygen atmosphere. However, erythroblast ATP concentration rapidly fell to less than $20 \%$ control levels when placed in nitrogen (Fig. 3A). This rapid decrease in cellular ATP concentrations was promptly restored to normal by oxygen (Fig. 3B).

\section{EFFECT OF OXYGEN ON HEMOGLOBIN SYNTHESIS}

In order to determine the effect of various oxygen tensions on hemoglobin synthesis, the radioactivity of the hemoglobin was determined in aliquots of reaction mixtures which had been incubated at $0 \%, 5 \%, 12 \%$, and $95 \%$ oxygen, respectively. Aliquots of incubation mixtures from each oxygen tension were removed at $1,2,3$, and $4 \mathrm{hr}$, the hemoglobin was precipitated with TCA and the incorporation of radioactive leucine determined. The results are shown in Figure 4. The total radioactivity incorporated into the TCA-precipitable protein was approximately equal at $5 \%$, $12 \%$, and $95 \%$ oxygen for $3 \mathrm{hr}$ and probably for $4 \mathrm{hr}$. Very little synthesis occurred in an environment of $0 \%$ oxygen. Total radioactivity in hemoglobin was used as the measure of synthesis since hemoglobin represents the majority of total cell protein in ery- throblasts. In a similar experiment, the pattern of $\mathrm{L}-\left[{ }^{14} \mathrm{C}\right]$ leucine incorporation into total protein was almost identical with that in Figure 4 when expressed as counts per min per mg protein.

\section{EFFECT OF OXYGEN ON TYPE OF HEMOGLOBIN SYNTHESIZED}

The effect of oxygen on the type of hemoglobin synthesized was studied by isolating the hemoglobin $\mathrm{A}, \mathrm{D}$, and $\mathrm{H}$ fractions and determining their total radioactivity. The hemoglobin in duplicate aliquots of incubation mixtures to which embryonic carrier chicken hemoglobin had been added was isolated by electrophoresis on starch block. The $\mathrm{L}-\left[{ }^{14} \mathrm{C}\right]$ leucine incorporated into each fraction was counted and the total radioactivity for each type of hemoglobin was calculated. The results are shown in Figure 5. At $5 \%, 12 \%$, and $95 \%$ oxygen, the major hemoglobin A contained most of the radioactivity, the minor hemoglobin D contained less, while the least amount of radioactivity was in hemoglobin $\mathrm{H}$. At $0 \%$ oxygen, the major hemoglobin A synthesis was similar at $1 \mathrm{hr}$ to that at other oxygen tensions, but fell thereafter when cell viability was low. No differences in the amount of hemoglobin $\mathrm{H}$ synthesized at each hour were observed.

\section{DISCUSSION}

Erythropoiesis in the avian embryo, like that of the mouse and probably man $(2,11,12,22,25)$, has a distinctive pattern of development. The early primitive red blood cell proceeds to a definitive lineage which provides erythroid cells in late embryogenesis, early extraembryonic life, and throughout adult life. The primitive and definitive cell lines have distinctly different morphology. Furthermore, changes in the types of hemoglobins synthesized 
are associated with the transition from the primitive to the definitive lines $(10,26,35)$. Although this developmental pattern is similar to that seen in the metamorphosis from tadpole to frog $(22$, 31 ), it differs from the pattern of progression from embryonic to adult hemoglobin which occurs in rabbits (38), sheep (40), and goats (45). In man the switch from hemoglobin $F$ to hemoglobin $A$ appears to occur in the same cell of the definitive line and is independent of cell locus $(5,19,27,44)$.

The switch from hemoglobin A to hemoglobin C which occurs in the erythropoietic response of certain sheep and goats which are anemic and/or hypoxic $(4,7,24,41)$ has been shown to be inducible by erythropoietin $(1,6,17,23,32,39)$. These two hemoglobins are synthesized in the same cells and the control of this transition appears to be at the nuclear level, probably via transcription $(3,18,33)$.

This is in contrast to the mechanism for control of differentiation in species which shift from a primitive to a definitive cell line. Although precursors of the definitive erythropoietic cells are erythropoietin responsive, the shift from a primitive cell line and the associated switch in hemoglobin synthesis are probably not induced by erythropoietin (35). However, the developmental changes in the pattern of hemoglobin in such species is also not entirely explained by changes in cell type, e.g., alterations in the rate of synthesis of hemoglobin $E_{1}, E_{1 I}$, and $E_{I I I}$ appear within the primitive cell line of the mouse $(16,38)$.

In recent studies of hemoglobin synthesis in cultured normoblasts from human fetal liver, differentiation of the normoblasts occurred in response to erythropoietin; however, a similar degree of differentiation occurred in fetal erythroid cells which had been maintained without erythropoietin. This suggests the possibility that differentiation in the fetal system may not be entirely erythropoietin dependent (37) and that nonerythropoietin stimulators and repressors of erythropoiesis may exist.

The erythroblasts in the present study were isolated from fetal liver by a modification of the technique of Hommes (21). The separation of isolated erythroblasts from hepatocytes provides a system in which hepatocytic factors are minimized. Thus, direct effects on and of erythroblasts can be observed. The viability of

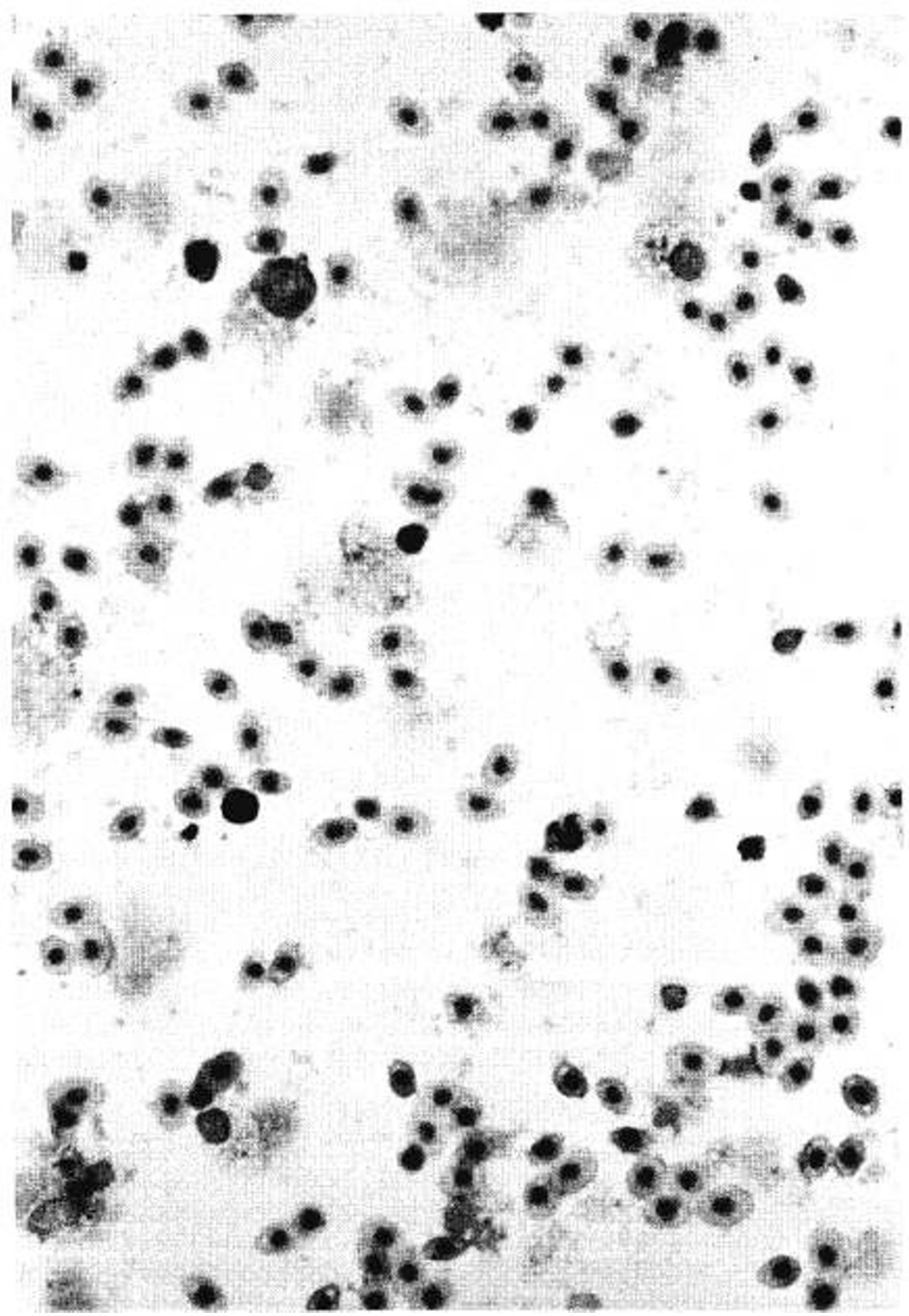

Fig. 2. Erythroblasts isolated from 14-day avian fetal livers. Cells were isolated as described in the text and stained with Wright's stain. (Magnification, $\times \quad 2,200$ before reproduction.) 
this system, as judged by microscopic and biochemical criteria, provides cells with excellent functional capacity. Cellular energy metabolism assessed by intracellular ATP levels is well maintained.

The present studies have shown that when there is sufficient oxygen for erythroblasts prepared from the livers of 14-day-old avain embryos to be viable, the amount of hemoglobin synthesized and the type is unchanged. Thus, after $1,2,3$, and $4 \mathrm{hr}$ of incubation in oxygen atmospheres of $5 \%, 12 \%$, and $95 \%$, there were similar rates of hemoglobin synthesis and the proportion of hemoglobins $\mathrm{A}, \mathrm{D}$, and $\mathrm{H}$ was unchanged. In addition, the rate of total protein synthesized was also similar at each oxygen tension. However, when the fetal hepatic erythroblasts were oxygen deprived there was a fall in ATP over a 1-hr period followed by a marked decrease in the synthesis of the major hemoglobin $A$ and the minor hemoglobin A fractions. The effects of hemoglobin D could not be ascertained since such changes would have been too small to detect quantitatively by the methods used in this study.

The oxygen tension of avian embryonic blood is not known; however, the fetal lamb in utero has an oxygen tension of $25 \mathrm{~mm}$ $\mathrm{Hg}$ which is equivalent to $3.5 \%$ oxygen (13) and is close to the $5 \%$ oxygen atmosphere which we studied. Since the physiologic optimum for most tissue culture cells is from $1 \%$ to $10 \%$ oxygen

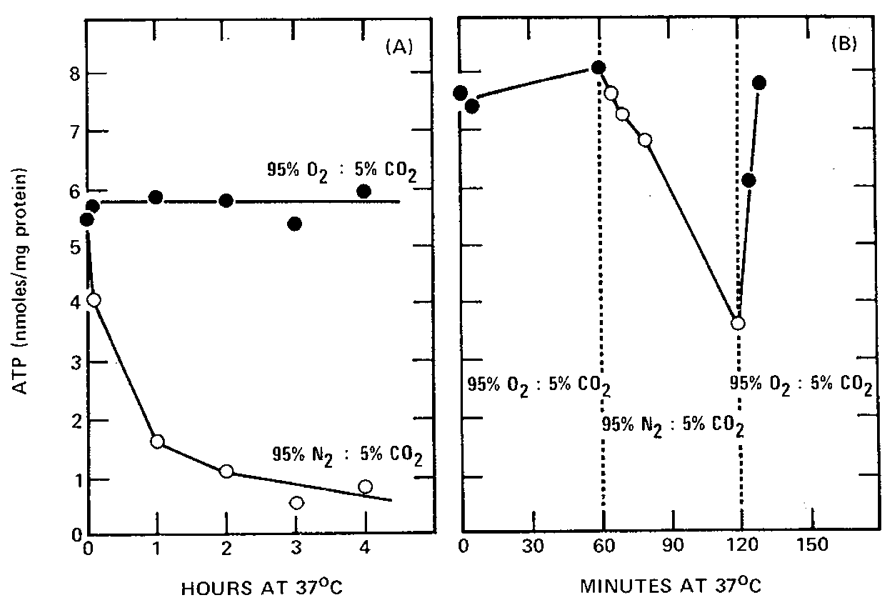

Fig. 3. Effect of oxygen on ATP concentrations in erythroblasts isolated from avian fetal livers. Cells were isolated, incubated, and prepared as described in the text.

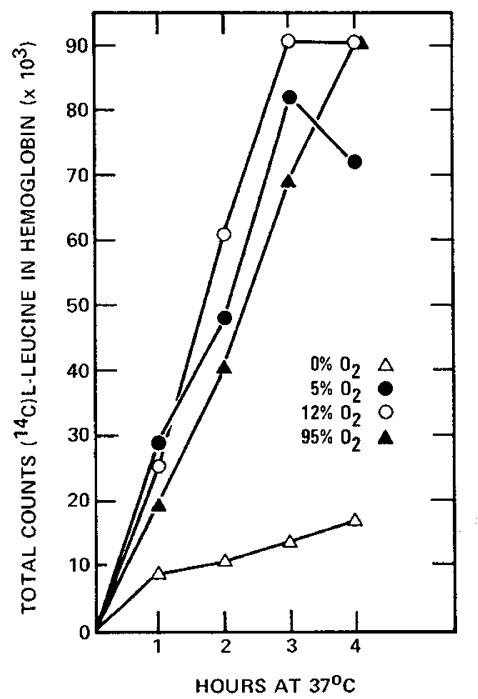

Fig. 4. Effect of various oxygen concentrations on hemoglobin synthesis in erythroblasts isolated from avian fetal liver. Cells were isolated, incubated, and prepared as described in text.

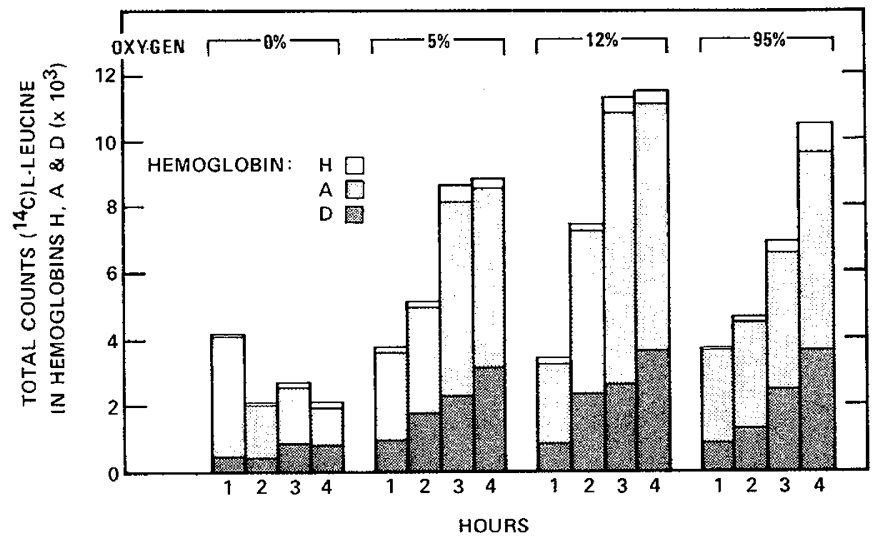

Fig. 5. Effect of various oxygen concentrations on type of hemoglobin synthesized in erythroblasts isolated from avian fetal livers. Cells were isolated, incubated, and prepared and the hemoglobin types separated by electrophoresis on starch block as described in the text.

$(20,34)$, the present study at $0 \%, 5 \%$, and $12 \%$ oxygen does not support a direct effect of oxygen on the type of hemoglobin synthesized at this stage of fetal development. However, the present studies were performed in avian embryos at an age when the switch from primitive to definitive cell lines is almost complete. Boyer et al. (5) have recently shown that the frequency of cells responsible for hemoglobin $F$ synthesis in adult man is not selectively influenced by exposure to hypoxia. A direct effect of oxygen on the type of hemoglobin synthesized could occur earlier in embryogenesis when the primitive cell line does not appear to be erythropoietin dependent and other nonerythropoietin controls are more likely to exist.

The possiblity exists that fetal liver may be a source of erythropoietin. Erythropoietin activity has been observed in long term fetal mouse liver cultures (46). However, as this tissue includes predominately hepatocytic cells, the observed activity may have resulted from hepatocytic cell function or by activation of a factor present in the media (including native horse serum) (46). In the present study, the isolated erythroblast system contains very few hepatocytic cells and no serum, and therefore it is unlikely that erythropoietin production by these cells would exist.

Oxygen delivery to the right and left lobes of the liver may be different in utero because of streaming of well oxygenated blood from the umbilical vein via the ductus venosus to the left lobe of the liver in contrast to deoxygenated blood from the portal vein which is delivered primarily to the right lobe (42). Since more erythropoietic foci exist in the right lobe than in the left lobe of the neonatal human liver (15), it is possible that oxygen at low tension does control the type and/or rate of hemoglobin synthesized in the human fetal liver.

The erythroblasts system described herein offers an excellent source of cells for short term tissue culture studies of the switch from human hemoglobin $\mathrm{F}$ to $\mathrm{A}$, as well as for studies of erythropoietin and nonerythropoietin stimulators of erythropoiesis such as cyclic nucleotides and the substituted steroids of placental and of nonplacental origin.

\section{SUMMARY}

A system is described for the isolation of erythroblasts from fetal liver. The isolated cells are functionally intact as judged by anatomic and biochemical criteria (e.g., intracellular ATP levels). The type and rate of $\mathrm{Hb}$ synthesis in these cells is not altered by oxygen tensions from $5 \%$ to $95 \%$.

\section{REFERENCES AND 'NOTES}

1. Adamson, J. W., and Stamatoyannopoulos, G.: Activation of hemoglobin C synthesis in sheep marrow culture. Science, 180: 310 (1973).

2. Bank, A., Rifkind, R. A., and Marks, P. A.: Regulation of globin synthesis. In: 
A. S. Gordon: Regulation of Hematopoiesis, Vol. 1, p. 701 (Appleton-CenturyCroft, New York, 1970)

3. Barker, J. E., Last, J. A., Adams, S. L., Nienhuis, A. W., and Anderson, W. F.: Hemoglobin switching in sheep and goats: Erythropoietin-dependent synthesis of hemoglobin $\mathrm{C}$ in goat bone marrow cultures. Proc. Nat. Acad. Sci. U.S. A., 70: 1739 (1973)

4. Blunt, M. H., and Evans, J. V.: Changes in the concentrations of potassium in the erythrocytes and in haemoglobin type in Merino sheep under a severe anaemic stress. Nature, 200: $1215(1963)$

5. Boyer, S. H., Belding, T. K., Margolet, L., Noyes, A. N., Burke, P. J., and Bell, W. R.: Variation in the frequency of fetal hemoglobin-bearing erythrocytes (F-cells) in well adults, pregnant women and adult leukemics. John Hopkins Med. J., 137: 105 (1975).

6. Boyer, S. H., Crosby, E. F., and Noyes, A. N.: Hemoglobin switching in nonanemic sheep. 1. Mediation by plasma from anemic animals. Johns Hopkins Med. J., 123: 85 (1968).

7. Braend, F., Efremov, G., and Helle, O.: Abnormal haemoglobin of sheep. Nature, 204: 700 (1964).

8. Brown, E. G., Liu, C. C., and McDonnell, F. E.: Unique electrode catheter for continuous monitoring of arterial blood oxygen tension in the newborn. Advan. Exp. Biol. Med., 37: 1103 (1973).

9. Brown, J. L., and Ingram, V. M.: Structural studies on chick embryonic hemoglobins, J. Biol. Chem., 249: 3960 (1974).

10. Bruns, G. A. P.: Ph.D. thesis (Massachusetts Institute of Technology, 1971).

11. Bruns, G. A. P., and Ingram, V. M.: Erythropoietic cells and hemoglobins of the chick embryo. Trans. Roy. Soc. London Ser. B., 266: 225 (1973).

12. Capp, G. L., Rigas, D. A., and Jones, R. T.: Evidence for a new haemoglobin chain ( $\delta$-chain). Nature, 228: 278 (1970).

13. Dawes, G. S.: Foetal and Neonatal Physiology (Yearbook Medical Publishers, Inc., Chicago, 1968)

14. Dieterlen-Lievre, F.: On the origin of haemopoietic stem cells in the avian embryo: An experimental approach. J. Embryol. Exp. Morphol., 33: 607 (1975).

15. Emery, J. L.: The distribution of haematopoietic foci in the infantile human liver. J. Anat., 90: 293 (1956).

16. Fantoni, A., De la Chapelle, A., and Marks, P. A.: Synthesis of embryonic hemoglobins during erythroid cell development in fetal mice. J. Biol. Chem., 244: 675 (1969).

17. Gabuzda, T. G., Schuman, M. A., Silver, R. K., and Lewis, H. B.: Erythropoietic kinetics in sheep studied by means of induced changes in hemoglobin phenotype. J. Clin. Invest., 47: 1895 (1968).

18. Garrick, M. D., Reichlin, M., Mattioli, M. and Manning, R. The anemiainduced reversible switch from hemoglobin $A$ to hemoglobin $C$ in caprine ruminants: Immunochemical evidence that both hemoglobins are found in the same cell. Develop. Biol. 30: 1 (1973).

19. Gitlin, D., Sasaki, T., and Vuopio, P.: Immunochemical quantitation of proteins in single cells. I. Carbonic anhydrase B, $\beta$-chain hemoglobin and $\gamma$-chain hemoglobin in some normal and abnormal erythrocytes. Blood, 32: 796 (1968).

20. Glinos, A. D., Vail, J. M., and Taylor, B.: Density-dependent regulation of growth in L cell suspension cultures. Exp. Cell Res., 78: 319 (1973).

21. Hommes, F. A., Oudman-Richters, A. R., and Molenaar, I.: The preparation of isolated fetal rat liver cells. Biochim. Biophys. Acta, 244: 191 (1971).

22. Huehns, E. R., Dance, N., Beaven, G. H., Keil, J. V., Hecht, F., and Motulsky, A. G.: Human embryonic haemoglobins. Nature, 20I: 1095 (1964).

23. Huisman, T. H. J., Lewis, J. P., Blunt, M. H., Adams, H. R., Miller, A., Dozy, A. M., and Boyd, E. M.: Hemoglobin C in newborn sheep and goats: A possible explanation for its function and biosynthesis. Pediat. Res., 3: 189 (1969).

24. Huisman, T. H. J., Van Der Helm, H. J., Visser, H. K. A., and Van Vliet, G.: Investigations on different haemoglobin types in some species of animals. In: J. H. P. Jonxis and J. F. Delafresnaye: Abnormal Haemoglobins: A Symposium (Blackwell Scientific Publishers, Oxford, England, 1959).

25. Ingram, V. M.: Embryonic red blood cell formation. Nature, 235: 338 (1972).

26. Ingram, V. M.: Determination and differentiation of erythropoiesis in early chick embryo. In: H. Kitchen and S. Boyer: Hemoglobins: Comparative Molecular Biology Models for the Study of Disease. Ann. N. Y. Acad. Sci., 24l: 93 (N. Y. Acad. Sci., U. S. A 1974).

27. Kabat, D.: The switch from fetal to adult hemoglobin in humans: Evidence suggesting a role for $\gamma-\beta$ gene linkage. In: $\mathrm{H}$. Kitchen and $\mathrm{S}$. Bover: Hemoglobins: Comparative Molecular Biology Models for the Study of Disease. Ann. N. Y. Acad. Sci., 241: 119 (N. Y. Acad. Sci., U. S. A., 1974).

28. Kunkel, H. G. Cepellini, R., Muller-Eberhard, U. and Wolf, J.: Óbservations on the minor basic hemoglobin component in the blood of normal individuals and patients with thalassemia. J. Clin. Invest., 36: 1615 (1957).

29. Lowry, O. H., and Passoneau, J. V.: A Flexible System of Enzymatic Analysis (Academic Press, New York, 1972).

30. Lowry, O. H., Rosebrough, N. J., Farr, A. L., and Randall, R. J.: Protein measurement with the Folin phenol reagent. J. Biol. Chem., 193: 265 (1951).

31. Maniatis, G. M., and Ingram, V. M.: Erythropoiesis during amphibian metamorphosis. I. Site of maturation of erythrocytes in Rana catesbeiana. J. Cell Biol., 49: 372 (1971a).

32. Moore, S. L., Godley, W. C., Van Vliet, G., Lewis, J. P., Boyd, E., and Huisman, T. H. J.: The production of hemoglobin C in sheep carrying the gene for hemoglobin A: Hematological aspects. Blood, 28: 314 (1966).

33. Nienhuis, A.W. Elson, N. A Barker J. E and Anderson, W. F. Hemoglobin switching in sheep and goats: Aspects of the molecular mechanism. In: $\mathrm{H}$. Kitchen and S. Boyer: Hemoglobins: Comparative Molecular Biology Models for the Study of Disease. Ann. N. Y. Acad. Sci., 24l: 566 (N. Y. Acad. Sci. U. S. A. 1974).

34. Richter, A., Sanford, K. K., and Evans, V. J.: Influence of oxygen and culture media on plating efficiency of some mammalian tissue cells. J. Nat. Cancer Inst., 49: 1705 (1972).

35. Rifkind, R. A., Cantor, L. N., Cooper, M. Levy, J., Maniatis, G. M., Bank, A., and Marks, P. A.: Ontogeny of erythropoiesis in the fetal mouse. In: $\mathrm{H}$. Kitchen and S. Boyer: Hemoglobins: Comparative Molecular Biology Modeis for the Study of Disease. Ann. N. Y. Acad. Sci., 24l: 113 (N. Y. Acad. Sci., U.S. A., 1974).

36. Schalekamp, M., Van Goor, D., and Slingerland, R.: Reevaluation of the presence of multiple hemoglobins during the ontogenesis of the chicken. J. Embryol. Exp. Morphol., 27: 543 (1972).

37. Shchory, M., and Weatherall, D. J.: Hemoglobin synthesis in human fetal liver maintained in short-term tissue culture. Brit. J. Hematol., 30: 9 (1975).

38. Steinheider, G., Medleris, H., and Ostertag, W.: In: Martin and Nowicki: Syntheses, Strucktur, und Funktion Des Hamoglobins, Vol. 225 (Lehmans Verlag, Munchen, West Germany, 1971).

39. Thurmon, T. F., Boyer, S. H., Crosby, E. F., Shepard, M. K., Noyes, A. N., and Stohlman, F., Jr.: Hemoglobin switching in non-anemic sheep. III. Evidence for presumptive identity between the $\mathrm{A} \rightarrow \mathrm{C}$ factor and erythropoietin. Blood, 36: 598, (1970).

40. Tucker, E. M.: Genetic variation in the sheep red blood cell. Biol. Rev., 46:341 (1971).

41. Van Vliet, G., and Huisman, T. H. J.: Changes in the haemoglobin types of sheep as a response to anaemia. Biochem. J., 93: 401 (1964).

42. Walsh, S. Z., Mever, W. W. and Lind, J.: The Human Fetal and Neonatal Circulation: Function and Structure, p. 312 (Charles C Thomas, Publisher, Springfield, Ill., 1974)

43. Wilt, F. H.: The control of embryonic hemoglobin synthesis. Advan. Morphogen., 6: 89 (1967).

44. Wood, W. G., Whittaker, J. H., Clegg, J. B., and Weatherall, D. J.: Haemoglobin synthesis in human bone marrow culture. Biochim. Biophys. Acta, 277: 413 (1972).

45. Wrightstone, R. N., Wilson, J. B., Miller, A., and Huisman, T. H. J. The structure of goat hemoglobins. IV. A third $\beta$ chain variant $(\beta E)$ with three apparent amino acid substitutions. Arch. Biochim. Biophys., 138:451 (1970).

46. Zucali, J. R., Stevens, V., and Mirand, E. A.: In vitro production of erythropoietin by mouse fetal liver. Blood, 46: 85 (1975).

47. We thank Dr. T. J. Gribble for helpful discussions and Ms. Diana T. Edmunds for expert technical assistance.

48. This investigation was supported in part by United States Public Health Service Research Grants HD 02147, HD 0049, HD 08977, and GM 00661 from the National Institutes of Health and the Rhode Island Hospital Research Fund.

49. Requests for reprints should be addressed to: H. C. Schwartz, M. D.. Section of Developmental Medicine, Department of Pediatrics, Stanford Medical Center, Stanford, Calif. 94305 (USA).

50. Accepted for publication April 2, 1976. 